\title{
Framing effects of information on investment risk perception ${ }^{\star}$
}

\author{
Beatriz Azevedo Monteiro ${ }^{1}$ \\ (i) https://orcid.org/0000-0002-4670-9862 \\ Email: biazevedo26@gmail.com

\section{Aureliano Angel Bressan²} \\ (D) https://orcid.org/0000-0002-9333-3394 \\ Email: aureliano@ufmg.br \\ ${ }^{1}$ Ceres Inteligência Financeira, Belo Horizonte, MG, Brazil \\ ${ }^{2}$ Universidade Federal de Minas Gerais, Faculdade de Ciências Econômicas, Departamento de Ciências Administrativas, Belo Horizonte, MG, \\ Brazil
}

Received on 02.04.2020 - Desk acceptance on 03.02.2020 - 4th version approved on 12.28.2020

Editor-in-Chief: Fábio Frezatti

Associate Editor: Fernanda Finotti Cordeiro

\begin{abstract}
The aim of this study is to verify whether the framing effects of past performance information affect the risk perception of individuals for fixed-income and variable income fund. We assess whether risk perception varies depending on how information is communicated to investors, considering the relevance of possible framing effects arising from how information is presented in investment funds' prospectuses and reports. This study is aimed at investors (individual and institutional) and fund industry regulators, highlighting the importance of past performance presentation. This article aims to contribute to the area by investigating how investors are influenced by varying perceptions of risk and return on fixed-income and variable-income assets, depending on information presentation format. The approach used is based on a $2 \times 2$ factorial quasi-experiment, in which format (within-subject) and time horizon (between-subjects) effects are tested in a sample of 143 respondents. Our results indicate that, for investment in a variable-income fund, a monthly yield presentation format leads to higher perceived risk, and that a framing emphasizing fund value evolution leads to higher perceived returns. As for investment in a fixed-income fund, the framing that emphasizes fund value leads to both higher perceived risk and higher perceived returns. When comparing the results for the two types of investments, the risk perception was higher for variable-income than for fixed income funds. However, perceived returns were higher for fixed income than for variableincome funds due to the framing effect, although realized returns do not corroborate this perception.
\end{abstract}

Keywords: framing effect, risk perception, investment funds, behavioral finance. 


\section{INTRODUCTION}

Monetary resources invested in the retail segment of the financial investment industry currently amounts to $\mathrm{R} \$ 1,855.8$ billion (Anbima, 2019b). The Brazilian Financial and Capital Markets Association (Anbima) classifies this volume into four major investment types: investment funds, which are governed by Instruction no. 555 (CVM, 2014); structured funds/Exchangetraded funds (ETFs); marketable securities; and savings. Between 2014 and 2018 investments in investment funds doubled in volume, from $\mathrm{R} \$ 280$ billion to $\mathrm{R} \$ 596$ billion, an increase from $22 \%$ to $33 \%$ in the investment fund industry's share in the total volume of financial investments over the period.

This trend can be explained in part by the fall in the basic interest rate, which led investors to seek more profitable investment options, such as investment funds (Goeking, 2018). In this context, understanding the investment profile of Brazilians, with a view to encouraging investment diversification beyond savings accounts, has been a subject of research in the financial sector $(B 3,2019)$. Moreover, the current scenario for long-term investment options is being affected by the Pension Reform debate, which tends to increase investors' interest in investment funds. Financial education in Brazil, however, falls short of other countries, hindered by the lack of initiatives to disseminate financial investment knowledge (Savoia, Saito, \& Santana, 2007).

In addition, research shows that, in general, individuals have difficulty in saving money at the expense of immediate consumption (Anbima, 2016; Mullainathan \& Thaler, 2000), often leading them to not save enough (Anbima, 2018a, 2018b; Thaler \& Benartzi, 2007), and their decisions on retirement are easily influenced (Mitchell \& Utkus, 2004; Thaler \& Benartzi, 2007). Moreover, financial service products are usually complex and difficult to assess in the long run (Pinheiro, 2008).

In view of this, our study was motivated by the analysis of several fact sheets containing essential information from investment funds to determine how the information about the fund is presented to investors for decision-making on resource allocation. These fact sheets usually present information on past performance in terms of cumulative return using a line chart, along with the fund's benchmark. The monthly return is often presented in a table format. The period for which past information is presented varies by manager and, in general, covers the fund's performance since returns first began to be calculated. For the most part, the Interbank Deposit Certificate (CDI) is the benchmark used for comparison, regardless of the fund's classification. In all fact sheets, the asset's (exposure) risk was presented, with the level of disclosure varying according to the financial agent.

Despite the differences observed in the sheets, there are good practice rules, conducts and codes for the promotion of financial products (Anbima, 2019b) that must be followed by all agents. These documents establish some rules; for example, past data must refer to the same period in every document, and they must indicate that the "profitability obtained in the past is not a guarantee of future results" (Anbima, 2019b, p. 27). It is also necessary to indicate the exposure risk for the asset, among other requirements.

However, the rules do not specify how information on past performance should be presented, nor do they define the timescale for which such information should be provided in advertisements, leaving such decision to the discretion of fund managers. This lack of a pre-established standard is what motivates our study, which investigates whether changes in how information is presented to investors affect their perception of risk, based on the factorial quasi-experiment proposed by Diacon and Hasseldine (2007), in which the authors tested the risk perception and decision making of individuals in the United Kingdom by testing the effects of different formats and timescales in which past performance information is presented.

Thus, this article aims to answer the following research question: Does the framing effects of a fund's past performance information (according to format and timescale) affect the investor's perception of risk?

\subsection{General Objective}

The main objective of this study is to analyze and assess investors' perception of risk according to the framing used to present information on past investment performance.

To this end, this study is divided into five sections, the first of which is this introduction. The second section refers to its theoretical foundation, presenting the theories that underpin the study. The methodology used is the subject of the third section, which describes the methods of analysis, the research hypotheses and the experiment 
design and construction. Next, the experiment results are presented. Finally, the last section presents the conclusion of the study and the main insights obtained, along with the study's limitations.

\section{THEORETICAL FRAMEWORK}

This section presents a brief review of the literature on the most relevant topics for the study design.

\subsection{Framing Effects and Decision Making}

According to the classical economic theory, human behavior has three main characteristics: unbounded rationality, utilitarianism (unbounded selfishness) and stable preferences (unbounded willpower) (Mullainathan \& Thaler, 2000). These characteristics depend on rational choices being dominant and invariant. This implies that it must be possible to order a set of options by preference and that this preference order must remain the same regardless of how those options are framed or described (Tversky \& Kahneman, 1984).

Tversky and Kahneman (1981) found evidence that these two axioms of rational choice are violated, presenting selected examples of systematic reversals in individual preferences according to how a problem was framed. For them, a decision problem is defined by the options given, the possible outcomes of these options and the conditional probabilities that relate outcomes to options; and then the decision can be framed according to each of these elements (Tversky \& Kahneman, 1981). This means that the same decision problem can be described in different ways, each one representing a possible framing of the problem.

According to Tversky and Kahneman (1981, p. 453), "the frame that a decision-maker adopts is controlled partially by the formulation of the problem and partially by the norms, habits, and personal characteristics of the decision-maker," and changing the initial frame can be very difficult, as individuals are normally unaware of alternative frames (Kahneman, 2012).

Since Tversky and Kahneman (1981) introduced the concept of framing effects, they have been the subject of several studies. For example, Dantas and Macedo (2013), Barreto, Macedo and Alves (2013), and Martins, Carvalho, dos Santos and da Silva (2013) investigated problem framing in terms of gains or losses, finding that changes in framing lead to changes in choice. In the same vein,
Silva, Barbosa, Teixeira and Reis Neto (2010) investigate whether framing effects (positive vs. negative) arising from recommendations to invest in the Bovespa stock exchange affects investors' perception, concluding that positive messaging make investors feel overconfident and encouraged to invest in stocks.

Also in this line, the experiments developed by Sun, $\mathrm{Li}$ and Bonini (2010) demonstrate that manipulating scale in graphic representations significantly affect option evaluation (in this case, the money amount of the scholarship vs. waiting time, and human relations vs. technical knowledge).

Kaufmann, Weber and Haisley (2013) carried out a series of experiments comparing the willingness of investors to make more risky allocations depending on how risk is communicated: numerical descriptions, graphical displays, experience sampling and a combination of these formats (called "risk tool" by the authors). Their findings indicate that presenting information through the risk tool reinforces the "commitment to the decision," expressed in increased confidence in the decision, in addition to a reduced overestimation of the probability of a loss, thus increasing the confidence of investors to accept more risk.

In this regard, Gentile, Linciano, Lucarelli and Soccorso (2015) also note that risk preferences and financial decisions are sensitive to how financial information is presented.

Following the same assumption, this study takes the factorial quasi-experiment of Diacon and Hasseldine (2007) as a basis to evaluate the effects of past performance information framing, in terms of both timescale (12 months or 45 months) and charts format - annual percentage returns or accumulated value of the asset representations often used in promotional materials for Brazilian investment funds. We thus expect to contribute to the literature on the topic by providing evidence of possible framing effects that may arise in fact sheets and performance reports provided by Brazilian investment funds. 


\subsection{Risk Perception}

Perception of risk is one of the most important factors considered in any type of decision-making (Ganzach, 2000). In this study, three of the risk perception dimensions described in the study by Diacon and Ennew (2001) are addressed: mistrust of the product or financial agent, the seriousness of adverse consequences and volatility of return. Similarly, Instruction no. 539 (CVM, 2013) considers, for assessing the investor's risk profile, the second and third of the dimensions mentioned above.

The risk arising from the feeling of mistrust in the product or in the financial agent is based on the probability of opportunistic behavior by agents, due to information asymmetry (Singh \& Sirdeshmukh, 2000). Weber, Siebenmorgen and Weber (2005) found that providing the name of the investment asset in the disclosure material affects risk perception (greater familiarity leads to less perceived risk). Jordan and Kaas (2002) found that the presence of the financial services agency's logo in print ads, despite not affecting the expected return, has a significant effect on the investment's risk perception.

The risk of serious adverse consequences, on the other hand, illustrated the loss aversion addressed by Tversky and Kahneman (1981). Loss aversion refers to the fact that the response to losses is stronger than the response to corresponding gains (Kahneman, 2012). Finally, the third of Diacon and Ennew's (2001) risk perception dimensions we investigate in this work is that of volatility of return, which is defined by the "perception of the fluctuations of return over time" (Jordan \& Kaas, 2002, p. 130).

\section{METHODOLOGY}

\subsection{Methods and Hypotheses}

To examine whether people's perceptions of risk is susceptible to framing effects, we conducted a quantitative research. This technique is indicated when the aim is to investigate a cause-and-effect relationship, verify specific assumptions and questions, in addition to its use as an analytical measurement technique (Creswell, 2007).

Data collection was made through a questionnaire based on the study by Diacon and Hasseldine (2007). Our aim in this study is to investigate whether changes in charts format and timescale used to present investment funds' past performance influence the individual's risk perception for each fund.
To that end, our experiment followed a two-factor factorial design. We opted for this model because it allows us to investigate how changes in input variables (factors) affect experiment results (Mukerjee \& Wu, 2011).

The experiment has two independent variables (factors): presentation format effect (fund value and monthly yield), which was varied within-subjects; and time horizon effect (short timescale - one year - and long timescale - four years), which was varied betweensubjects. Considering these criteria, the research subjects were divided into four groups, all answering their respective group's questionnaire, as shown in Table 1.

Table 1

Questionnaires' design

\begin{tabular}{|c|c|c|c|c|}
\hline \multirow{2}{*}{ Treatment group } & \multicolumn{2}{|c|}{ Format: fund value } & \multicolumn{2}{|c|}{ Format: monthly yield } \\
\hline & BOVA11 & IMA-General & BOVA11 & IMA-General \\
\hline $\mathrm{A}$ & Long (A) & Short (D) & Long (E) & Short $(H)$ \\
\hline B & Long (A) & Long $(\mathrm{C})$ & Long (E) & Long $(\mathrm{G})$ \\
\hline $\mathrm{C}$ & Short (B) & Short (D) & Short (F) & Short $(\mathrm{H})$ \\
\hline $\mathrm{D}$ & Short (B) & Long $(\mathrm{C})$ & Short (F) & Long $(\mathrm{G})$ \\
\hline
\end{tabular}

Note: Fund code letter showed in parenthesis.

Source: Elaborated by the authors.

These independent variables were tested for the risk perception variable, which was separated into three types (Diacon \& Ennew, 2001): mistrust risk, which concerns the credibility of the product or agent's service (Singh \&
Sirdeshmukh, 2000); risk of loss, as in Kahneman and Tversky's conception of loss aversion (1979); and, finally, the perception of risk associated with the asset's volatility was tested. 
In addition, a supplementary question was added to this section about the asset's yield in comparison with the return from savings accounts, in order to measure the individual's expectations regarding the yield on that investment fund according to a scale standardized for all funds (named "A" to "H"). Questions about risk perception and expected yield were asked for each fund presented in the questionnaire; questions 1 to 7 (all questions are presented in the Appendix) were thus repeated four times in each questionnaire.

Moreover, there is a section for the simultaneous analysis of investment funds' types, which has three supplementary questions: the maximum amount a friend should pay to receive advice from a financial analyst (question 9); the level of difficulty in understanding the performance charts presented (question 10); and whether information on past performance is helpful in making investment decisions (question 11) (Diacon \& Hasseldine, 2007). These questions are aimed at helping to interpret the results obtained in the main question.

In this study, we tested three hypotheses, namely:

H1: The participants' average risk perception varies according to the format of the past performance charts.

$\mathrm{H} 2$ : The participants' average risk perception changes based on framing effects arising from the timescale of past performance.

H3: The participants' average risk perception varies between types of investment funds.

As Diacon and Hasseldine's (2007) original research questionnaire was written in English, a free translation into Portuguese was made for its application in Brazil. The questionnaire was built using a Google virtual platform (Google Forms) and was distributed to participants who work or invest in the financial market and to students at the Faculty of Economic Sciences of the Federal University of Minas Gerais (UFMG), using snowball sampling to reach new respondents.

Data collection using this method makes use of existing relationships between individuals who share the characteristics of interest for the study (Biernacki \& Waldorf, 1981). In general, according to Vinnuto (2014), snowball sampling allows a continuous collection of data that takes advantage of the social networks of the initial research subjects to increase sample size.

The assignment of individuals to treatment groups was defined by the day of birth of the research subject. Days 1 to 31 were grouped into four intervals (1 to 8; 9 to $16 ; 17$ to 24 and 25 to 31 ) and a question at the beginning of the questionnaire asked participants to select the interval to which their birthdays belonged, directing them to the corresponding treatment group questionnaire (A, B, C and D, respectively). We chose to use only the day due to the several studies showing the existence of birth seasonality (month/day; day of the week) (Bobak \& Gjonca, 2001; Dickert-Conlin \& Chandra, 1999; Haandrikman, 2004; Polasek, Koleie, Vorko-Jovié, Kern, \& Rudan, 2005). Thus, although group assignment was not random, this procedure prevents seasonality effects on sampling resulting from using the month and/or the day of the week, representing an allocation method not influenced by the researcher that seeks to distribute the questionnaires between the groups as close as possible to the desired proportion of $25 \%$ per group.

To prepare the charts, and in order to replicate the choice between variable and fixed-income funds, as used by Diacon and Hasseldine (2007), we decided to use the Bovespa's BOVA11 index fund as a proxy for variableincome funds in the Brazilian market (Figure 1). For the fixed-income proxy, we used Anbima's IMA-General series, since at the time of the experiment there was no historical series available for fixed-income index funds in the Brazilian financial market containing data since 2014 (Figure 2).

It should be noted that some adjustments were made in relation to the charts used in the original study. First, the "long" charts show data for 48 months (4 years) instead of 45 months. This change was made because, during the preparation of the questionnaire, we observed that there were no abrupt changes/losses in the charts, that is, the 48-month chart shows the same trend as the 45-month chart. This also makes them more intuitive, since this timescale is equivalent to 4 one-year cycles and thus corresponds to the four times the 1-year "short" charts.

Another adjustment was made in two aspects of the expected yield charts, namely: the yield is presented in monthly rates instead of annual; and yields are presented on a monthly basis instead of quarterly. These changes were necessary due to the particularities and conventions of the Brazilian financial market, which has historically shown large variations and high yields on a monthly basis compared with international standards; thus, presenting yields on an annual or quarterly basis, as in the original study, could distort the results obtained. Moreover, in the Essential Informations Fact Sheet of investment funds, yields are shown on a monthly basis (in monthly values) for the 1-year timescale and the accumulated value for each year (non-annualized) for longer time horizons (CVM, 2014). Thus, to make possible to compare the long- and short-term charts, we adopted the standard for short time horizons of the Brazilian Securities and Exchange Commission (CVM). 
The charts were incorporated into the questionnaire (Figures 1 and 2) without the originals' explanation in parenthesis. In a preliminary analysis, we can observe a growth trend in the 4-year timescale for the variableincome fund, even with the high variation shown. While in the short-term chart the high variation of the fund's yield is more evident, with a fall occurring in the middle of the time horizon and the recovery of the fund's value reaching levels slightly above those of the beginning of the time horizon.

Fixed-income charts, in turn, do not show great variations between long and short timescales, as was already expected in the case of this type of fund. However, the short-term chart gives the impression of a greater variation than the long-term chart, due to a drop in June 2018, which becomes more pronounced on this time horizon.

Moreover, a comparison between the charts presenting monthly yields on fixed-income and variable-income funds clearly shows that the fixed-income fund, although more stable, has significantly lower yields than the variable-income fund.

After preparing the questionnaire, a pre-test was carried out with a group of financial analysts and students to assess whether that the changes made to the original questionnaire would not impair its understanding, especially due to the translation and the use of the Google Forms platform. The final version of the questionnaire is available in the Appendix.
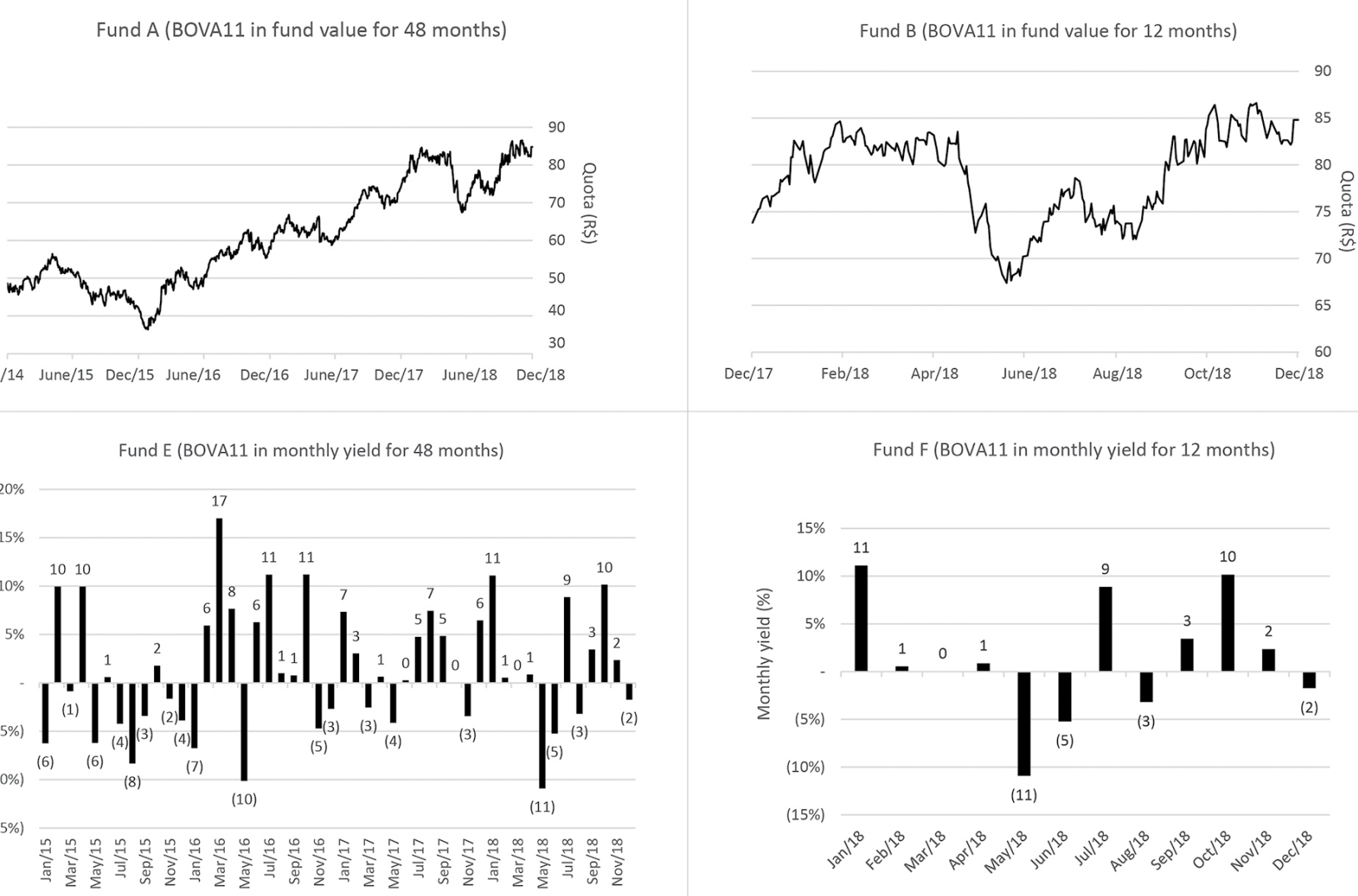

Figure 1 Variable-income (BOVA11) charts presented in the questionnaire Source: BlackRock (2019). 


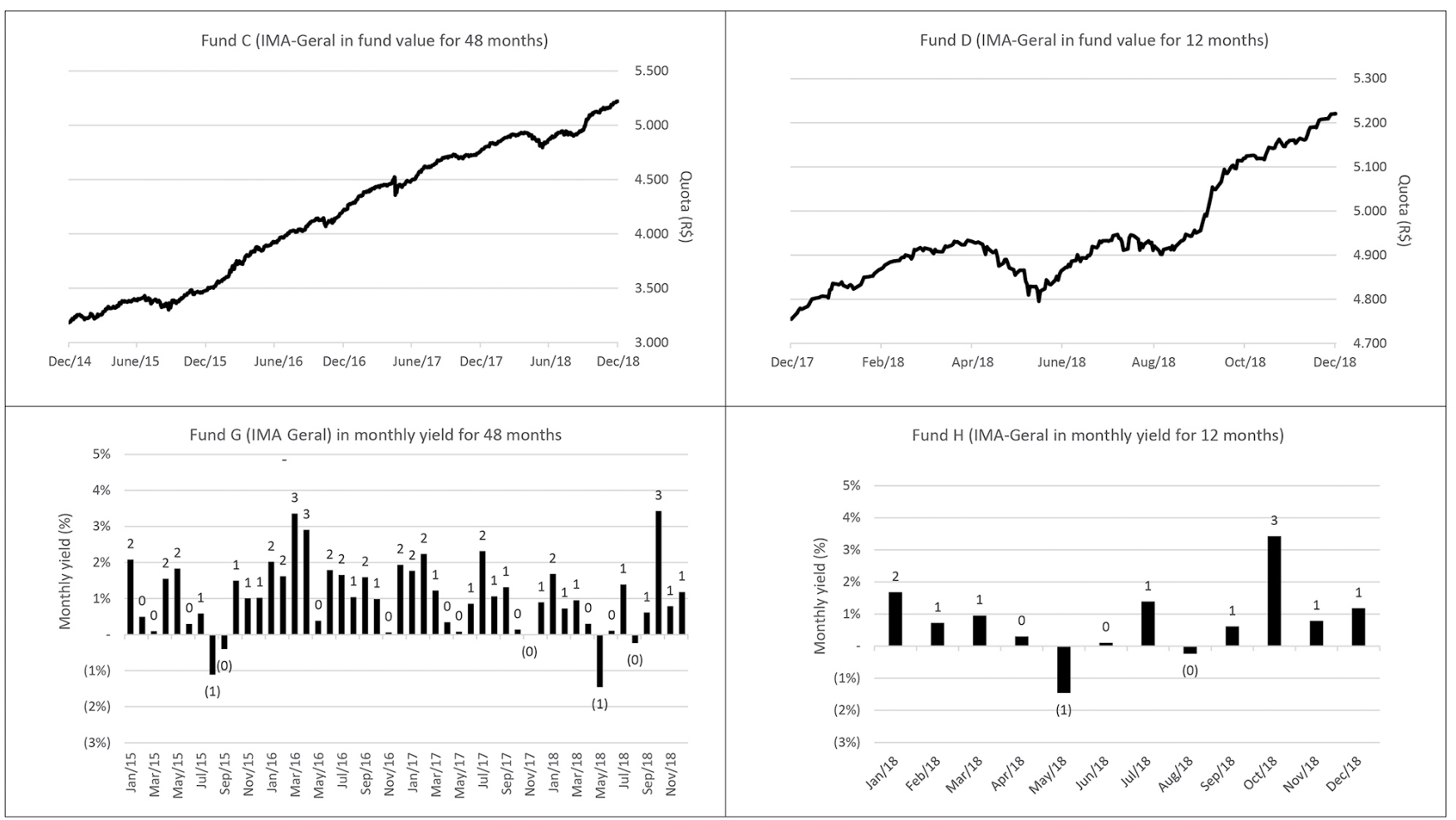

Figure 2 Fixed-income (IMA-General) charts presented in the questionnaire

Source: Anbima (2019b).

\subsection{Statistical Procedures}

For the analysis of results, we used 2-factor repeated measures ANOVA (split-plot design) for parametric results.

The 2-way ANOVA methodology allows testing the effect of each independent variable on the experiment results, as well as assessing the interaction between the factors. Moreover, our experiment has 4 independent samples to test time horizon effects and two related samples to test format effects. This is because the same individual is tested for the format effect (within-subject factor) and for the time horizon effect, which is tested on different individuals, that is, for between-subject factors. This configuration is necessary in the 2-way
ANOVA, since a possible correlation between format effect responses must be considered in the statistical test because they come from the same subject (Park, Cho, \& Ki, 2009).

The ANOVA performed tests for the null hypothesis that all average scores are equal, with the alternative hypothesis being the presence of at least one different average. However, this method does not indicate, in the case of the null hypothesis being rejected, for which group the average was different. Thus, we performed a post-hoc analysis using the Bonferroni multiple comparison test to identify the relationship of averages group to group. It should also be noted that this test controls for type 1 error (rejection of a true null hypothesis) (Chagas, 2016) for the time horizon variable.

\section{RESULTS}

\subsection{Sample Characteristics}

As explained in the previous section, the questionnaire application involved a snowball sampling strategy, with a total of 143 respondents. Respondents were assigned to each treatment group - or type of questionnaire - according to their day of birth, which resulted in a distribution of respondents close to $25 \%$ to each group (Figure 3). 
Altogether, 48 of the respondents are women (34\%) and 94 are men (66\%), generating a ratio of approximately $1: 2$. This proportion was maintained in the analysis of each treatment group.

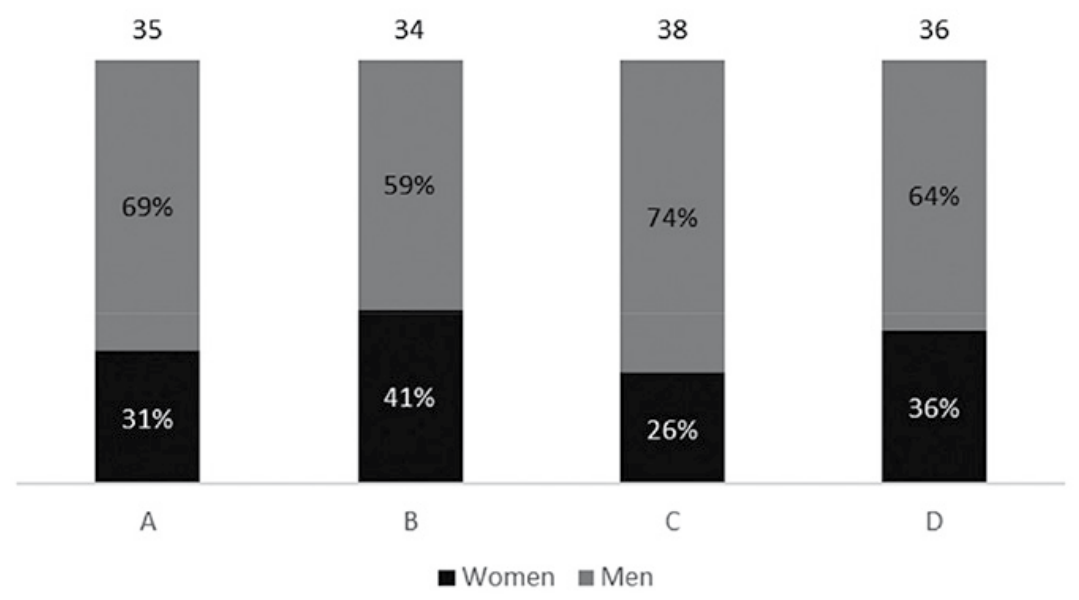

Figure 3 Percentage and total number of respondents by gender by treatment group Source: Elaborated by the authors.

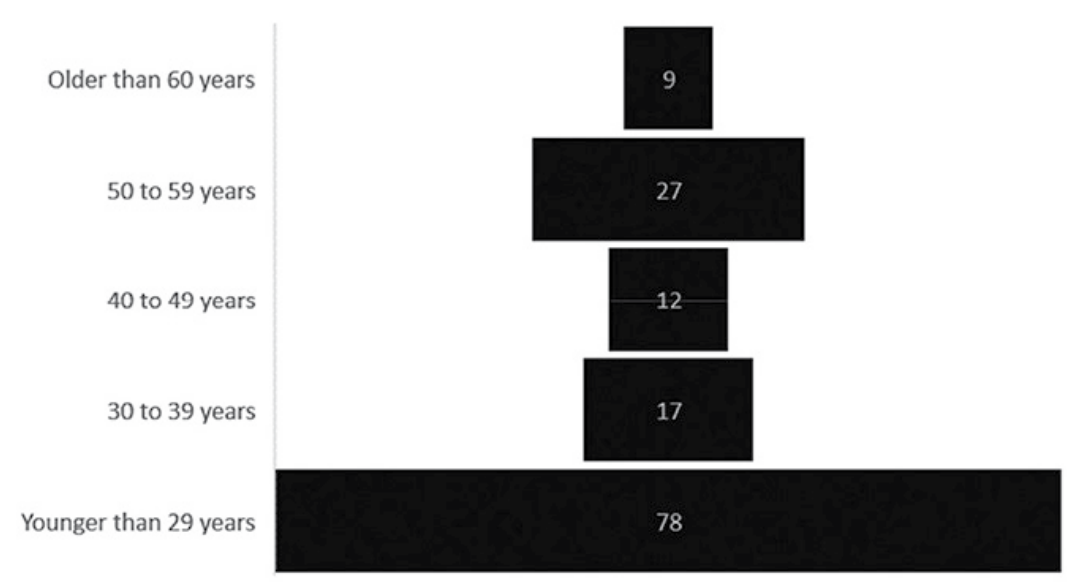

Figure 4 Number of Respondents by Age Group

Source: Elaborated by the authors.

With regard to age groups, $54.5 \%$ of respondents are 29 years old or younger (Figure 4). However, despite the predominantly young profile of the sample, the second largest category was of individuals aged 50-59. This pattern was maintained both among men and women and for each treatment group, with the exception of type $C$, which had a slightly higher proportion of respondents between 50 and 59 years old.

As for education level, most people have at least college education or are attending college (97\%), with 47 respondents having a graduate degree (higher level of education in the questionnaire). Regarding income level, most individuals have an income above 5 minimum monthly wages ( $56 \%$ of the sample), and $29 \%$ between 1 and 5 minimum monthly wages.
In addition to these socioeconomic questions, two more questions were added to the questionnaire: whether the person has financial investments and whether the person operates in the financial market, which are relevant to the research purpose. In the research sample, only 19 participants (13.29\%) work in the financial market, with 13 of them having worked for up to 5 years and 2 respondents for more than 16 years.

As for investment habits, 31 respondents (21.68\%) have no investments and only 6 individuals invest only in variable-income funds. It is also possible to conclude that the majority of people who invest in variable-income assets also invest in fixed-income assets (39 participants). Thus, 67 individuals have only fixed-income investments. Moreover, this distribution remains almost the same for all questionnaire formats. 


\subsection{Risk Perception}

This study aims to test two hypotheses regarding risk perception: whether the subject's risk perception is affected by both format framing effects and time horizon effects. The 2-way repeated measures ANOVA referred to earlier provides the answer to both hypotheses.

The results are shown in Tables 2 and 3 for BOVA11 and IMA-General, respectively. The column identified by "Format test" (Wilks' Lambda) shows test results for the format effect (within-subject); the "Time test" column $(F)$ presents the p-value for the test for the time horizon effect (between-subjects); the "Interaction test" column indicates the result of the interaction between the factors, which if significant indicates the result of the subsequent tests performed; and the last column indicates the Bonferroni post-hoc test findings, if any. The complete tables with the averages for each group are available on request.

\subsubsection{The effect of format and timescale on BOVA11 fund}

The results for the BOVA11 variable-income fund (Table 2) show that the timescale effect had no impact on any question about risk perception, since all the p-values for the between-subjects test were higher than 0.05 significance level set for this study. This fact is worthy of attention, as it is possible to observe a significant change in trends between the short and long charts.

Table 2

ANOVA test statistics for BOVA11 risk perception

\begin{tabular}{|c|c|c|c|c|c|c|c|}
\hline \multicolumn{2}{|l|}{ BOVA11 } & \multicolumn{2}{|c|}{ Format Effect } & \multicolumn{4}{|c|}{ Tests } \\
\hline Type of risk & Question & Line & Bar & Format test & Time test & Interaction test & Bonferroni test \\
\hline \multirow{2}{*}{ Mistrust } & 2 & 5.22 & 5.46 & $0.054^{*}$ & 0.154 & 0.972 & None \\
\hline & 6 & 3.86 & 4.55 & $0.000^{* * *}$ & 0.968 & 0.558 & None \\
\hline \multirow{2}{*}{ Loss } & 3 & 5.13 & 5.78 & $0.000^{* * *}$ & 0.773 & 0.387 & None \\
\hline & 4 & 3.42 & 4.97 & $0.000^{* * *}$ & 0.889 & 0.970 & None \\
\hline \multirow{2}{*}{ Volatility } & 1 & 4.72 & 5.98 & $0.000^{* * *}$ & 0.673 & 0.434 & None \\
\hline & 5 & 5.73 & 5.93 & $0.070^{*}$ & 0.150 & 0.576 & None \\
\hline Savings Account Yields & 7 & 5.57 & 4.77 & $0.000^{* * *}$ & 0.450 & $0.030^{* *}$ & None \\
\hline
\end{tabular}

Note: ${ }^{*} p$-value $<0.1 ;{ }^{* *} p$-value $<0.05 ;{ }^{* * *} p$-value $<0.01$.

Averages by type of chart (Line - fund value; Bar - monthly yield) grouped for all treatment groups. Values closer to 7 indicate higher perceptions of risk. The contents of questions 1 to 7 are presented in the Appendix.

Source: Elaborated by the authors.

However, format factor tests mostly resulted in p-values lower than 0.05 , that is, averages for "line" (or fund value) and "bar" (or monthly yield) differ statistically. Therefore, the average values shown in Table 2 allow us to conclude that the framing of past performance in terms of monthly yields increases the perception of risk in our research sample, regardless of the chart's timescale.

Finally, for question 7 , on the fund's expected yield compared with the yield on a savings account, complementary analysis are carried out to identify the reason for the interaction. For this purpose, ANOVA was separately performed for each of the factors. The test was then performed twice for the timescale factor: one for the average yield effect ("bar") and another for the fund value effect ("line"), which resulted in non-significant p-values (0.419 and 0.076, respectively). Moreover, the post-hoc tests did not indicate any grouping of treatment groups for any of the format effects. However, it should be noted that the average for group C "line" effect is lower than for other format effect averages.
For the format factor, the test was repeated 4 times to assess the effect of this factor on each treatment group. Groups A, B and D tests resulted in significant p-values, that is, they show a format effect impact on these groups. For group $\mathrm{C}$, the result did not indicate any difference in format effect averages ( $p$-value $=0.333$ ). Thus, the results of these tests indicate that for treatment group $\mathrm{C}$ there is no format effect impact on the variable; and for the other groups, a higher expected yield is perceived in the line chart than in the bar chart. Specifically regarding the line chart, the type $\mathrm{C}$ (short/short) timescale effect shows a relatively lower average than that of the other timescales, but this effect alone could not reject the null hypothesis of the general timescale effect.

In summary, for the BOVA11 variable-income fund, when past performance is presented in terms of monthly yields, participants perceive a higher risk than in the fund value chart. In contrast, a higher expected yield is perceived in the line chart. That is, past performance presented in a bar chart is considered more risky and generating lower 
expected yields than in a line chart presentation, regardless of the time horizon covered by the charts.

These results are partially compatible with those from the original study by Diacon and Hasseldine (2007): as in the original results, timescale effects were not significant for risk perception and, in general, the perception of risk was also higher when past performance was presented in terms of monthly yields. However, contrary to the findings of Diacon and Hasseldine (2007), which showed higher expected yields on the variable-income fund for the bar chart presentation, in this study the expected yield is higher when presented in terms of fund value (line) for our study sample.

\subsubsection{The effect of format and timescale on IMA fund}

For the IMA fixed-income investment fund, the ANOVA results (Table 3 ) showed some variations in impact. As no interaction between the factors was found for any of the questions, it was not necessary to test for simple effects.

Table 3

ANOVA test statistics for IMA risk perception

\begin{tabular}{|c|c|c|c|c|c|c|c|}
\hline \multicolumn{2}{|l|}{ IMA } & \multicolumn{2}{|c|}{ Format effect } & \multicolumn{4}{|c|}{ Tests } \\
\hline Type of risk & Question & Line & Bar & Format test & Time test & Interaction test & Bonferroni tests \\
\hline \multirow{2}{*}{ Mistrust } & 2 & 4.43 & 3.97 & $0.00^{* * *}$ & $0.004^{* * *}$ & 0.59 & $(\mathrm{~A}$ e $\mathrm{D})(\mathrm{B}, \mathrm{C}$ e $\mathrm{D})$ \\
\hline & 6 & 3.70 & 3.62 & 0.49 & 0.53 & 0.89 & None \\
\hline \multirow{2}{*}{ Loss } & 3 & 4.38 & 4.08 & $0.03 * *$ & $0.052 *$ & 0.94 & $(A, B$ e $D)(A, C, D)$ \\
\hline & 4 & 2.95 & 2.93 & 0.88 & 0.26 & 0.35 & None \\
\hline \multirow{2}{*}{ Volatility } & 1 & 3.34 & 3.43 & 0.55 & $0.00^{* * *}$ & 0.63 & $(\mathrm{~A}$ e C $)(\mathrm{B}$ e $\mathrm{D})$ \\
\hline & 5 & 5.20 & 4.52 & $0.00^{* * *}$ & 0.65 & 0.41 & None \\
\hline Savings Account Yields & 7 & 5.57 & 5.10 & $0.00^{* * *}$ & 0.55 & 0.13 & None \\
\hline
\end{tabular}

Note: ${ }^{*} p$-value $<0.1 ;{ }^{* *} p$-value $<0.05 ;{ }^{* * *} p$-value $<0.01$.

Format effect averages by type of chart (Line - fund value; Bar-monthly yield) grouped for all treatment groups. Values closer to 7 indicate higher perceptions of risk. The contents of questions 1 to 7 are presented in the Appendix.

Source: Elaborated by the authors.

The analysis of the instrument for each question shows that in question 2 , about receiving biased information, both the format effect and the timescale effect influence risk perception. For question 6 (on how trustworthy are product and service providers), which seeks to measure the same type of risk, the test did not show any impact caused by the factors tested. Even so, the analysis shows that for the mistrust risk the respondents' risk perception is higher for the line chart than for the bar chart. Moreover, the respondent's risk perception rose considerably when the short-term IMA was shown alongside the long-term BOVA11 chart - Group A (Table 4).

Table 4

Question 2 averages by format and timescale for the IMA Fund

\begin{tabular}{|c|c|c|c|c|c|c|}
\hline \multirow[b]{2}{*}{ Type of risk } & \multirow[b]{2}{*}{ Question } & \multirow[b]{2}{*}{ Treatment group } & \multirow[b]{2}{*}{ Time } & \multicolumn{2}{|c|}{ Format Effect } & \multirow{2}{*}{$\begin{array}{l}\text { General format } \\
\text { average }^{1}\end{array}$} \\
\hline & & & & Line & Bar & \\
\hline \multirow{5}{*}{ Mistrust } & \multirow{5}{*}{2} & A & Short & 5.23 & 4.49 & 4.86 \\
\hline & & B & Long & 4.00 & 3.53 & 3.76 \\
\hline & & $\mathrm{C}$ & Short & 4.11 & 3.82 & 3.96 \\
\hline & & $\mathrm{D}$ & Long & 4.39 & 4.06 & 4.22 \\
\hline & & Total & Grouped & 4.43 & 3.97 & 4.20 \\
\hline
\end{tabular}

Note: ${ }^{1}$ Bonferroni tests indicated by formatting (bold or italic).

Averages by treatment group (timescale and format) for question 2: "Is there a risk of receiving unsound and biased information from those who sell or recommend this product?"

Source: Elaborated by the authors. 
The same is true for the loss risk: while question 3 about serious negative consequences - shows impacts from both the format effect and the timescale effect (even considering p-value $>0.05$ for Bonferroni tests in the Table 3, showing that groups $B$ and $C$ have different averages); question 4 about "the friend losing all the money invested" has the same average for all combinations of factors. For this risk statement, observing question 3, for which there is format effect impact, the survey respondents indicate that the fund value chart is more risky than the monthly yields chart. It is also interesting to observe a dichotomy: group $\mathrm{B}$, in which the two types of funds are in the "long" time horizon, has the lowest perception of loss risk; group $\mathrm{C}$, in which both types of fund are presented in the "short" time horizon, has the highest risk perception (Table 5).

Table 5

Question 3 averages by format and timescale for the IMA Fund

\begin{tabular}{|c|c|c|c|c|c|c|}
\hline \multirow{2}{*}{ Type of risk } & \multirow{2}{*}{ Question } & \multirow{2}{*}{ Treatment group } & \multirow{2}{*}{ Time } & \multicolumn{2}{|c|}{ Format Effect } & \multirow{2}{*}{$\begin{array}{c}\text { General format } \\
\text { average }^{1}\end{array}$} \\
\hline & & & & Line & Bar & \\
\hline \multirow{5}{*}{ Loss } & \multirow{5}{*}{3} & A & Short & 4.49 & 4.14 & 4.31 \\
\hline & & B & Long & 3.71 & 3.56 & 3.63 \\
\hline & & $\mathrm{C}$ & Short & 4.68 & 4.34 & 4.51 \\
\hline & & $\mathrm{D}$ & Long & 4.58 & 4.25 & 4.42 \\
\hline & & Total & Grouped & 4.38 & 4.08 & 4.23 \\
\hline
\end{tabular}

Note: ${ }^{1}$ Bonferroni tests indicated by formatting (bold or italic).

Averages by treatment group (timescale and format) for question 3: "How serious could the consequences of owning this product be, should it prove unsatisfactory?"

Source: Elaborated by the authors.

As for the questions about the volatility risk, question 5 - how great the risk of the investment value is going down or up - points to an impact of the format effect on the averages; and question 1 , about product uncertainty, is only influenced by the timescale effect. It is worth mentioning that Bonferroni tests reinforce this difference arising from varying timescales, since the charts presented in treatment groups $\mathrm{A}$ and $\mathrm{C}$ are "short" (first grouping) and groups B and D present the "long" time horizon (second grouping). These two analysis combined show that, when there is an impact of the format effect, the line chart is considered riskier; and when there is an impact of the time horizon, the volatility risk of is perceived as higher for the charts in which only 12 months of past performance are presented (Table 6).

Table 6

Question 1 averages by timescale for the IMA Fund

\begin{tabular}{|c|c|c|c|c|}
\hline Type of risk & Variable & Treatment group & Time & Format average \\
\hline \multirow{5}{*}{ Volatility } & \multirow{5}{*}{ Question 1} & A & Short & 3.96 \\
\hline & & B & Long & 2.90 \\
\hline & & $\mathrm{C}$ & Short & 3.72 \\
\hline & & $\mathrm{D}$ & Long & 2.92 \\
\hline & & Total & Grouped & 3.38 \\
\hline
\end{tabular}

Note: Averages by treatment group (timescale and format) for question 1: "How much uncertainty is there in terms of the expected return for this product?"

Source: Elaborated by the authors.

Finally, for question 7, about the fund's yield compared with the savings account's yield, we only found an impact from the format effect on the respondents' perception about this variable, with the fund value chart being perceived as representing higher yields for the respondent than the monthly yield chart. 
In summary, although the impact of the factors varies for each question, there is a pattern to the responses in which: (i) the line chart for the fixed-income fund is generally perceived as representing more risk than the bar chart, and (ii) a short time horizon for past performance presentation leads to higher risk perception. Additionally, respondents attribute a higher yield to the "fund value" chart than to the "monthly yield" chart. This leads to a combination in which the chart with the higher perceived risk is the one that generates the perception of higher expected yields. These results differ from those obtained by Diacon and Hasseldine (2007), who did not find either significant format effects or significant timescale effects for fixed-income funds in terms of risk perception and expected yields.

\subsubsection{Framing effects and the types of investment fund}

The comparison between the results obtained shows that, while a higher risk is perceived in the bar chart for the variable-income fund (BOVA11), the line chart generates the perception of a more risky investment for the fixedincome fund. Kahneman and Tversky's Prospect Theory (1979) offers a possible explanation for this phenomenon: the "monthly yield" chart is a graphical presentation of results in terms of gains or losses. Thus, as the variableincome fund presents more and greater negative returns, when its presentation highlights variation and not the final yield, such framing may imply a greater feeling of loss aversion in the respondents. This does not happen with the IMA, as it does not show any major negative variations in monthly yields. Thus, despite presenting low yields, the "bar" chart removes the variations perceived in the "line" chart.

For both types of fund, the fund value chart generates a feeling of higher expected yields. In other words, in the combination for the IMA fixed-income fund, the perceived risk-return ratio follows the same pattern: the asset with a higher perceived risk, also has a higher expected yield. However, this combination does not hold for the variable-income fund. This implies that framing past performance in terms of fund value can create a perception bias, in which there is a lower perceived risk and a higher expected yield - inflating the investor's perceived risk-return ratio.

Regarding the timescale effect on risk perception, it only had an impact for the fixed-income fund. This is interesting, since the variable-income fund charts clearly shows the global trend changing when comparing the time horizons presented. However, the IMA fixedincome index maintains its global growth trend in the two timescale frames, with only a drop in the middle of the "short" time horizon, but which soon resumes its growth trend. This result suggests that the impact of a sharp fluctuation is perceived more intensely in environments where fluctuations are usually small; thus, the unusual abrupt drop shown in the chart represented a salience factor (Mussweiler \& Schneller, 2003) for respondents, who were more inclined to make judgments based on the extreme importance attributed to that drop (Kahneman, 1999).

Finally, ANOVA was repeated to test the third hypothesis of this study, assessing whether risk perception and expected yields vary significantly between BOVA11 and IMA for each type of chart, considering timescale effects. As shown in Table 7, the risk values attributed to the variable-income fund are, in general, statistically higher than those attributed to the fixed-income fund. This result shows that neither format effects nor time horizon effects altered the universal risk ratio: fixedincome assets present less risk than variable-income assets for the survey respondents.

However, this relationship was not maintained in terms of yields (question 7): the expectation of yields that are higher than the savings accounts was greater for the fixed-income fund's "bar" charts and for the group C "line" chart - for the other groups' (A, B and D) "line" charts, the average for BOVA11 was higher, but the difference observed was not significant. Line chart results then show that respondents were more sensitive to the observed trend than to the chart scale, since higher averages for BOVA11 were expected. This idea is addressed in the study by Griffin and Tversky (1992), in which people give more importance to the strength of the recommendation (trend) than to the weight of the evidence (chart scale).

For the bar chart, a possible explanation for the expectation of higher yields on the IMA fund is the loss aversion phenomenon (Kahneman \& Tversky, 1979), which we discussed earlier, with people penalizing the variable-income fund for the negative yields presented, while ignoring the fact that it also offers high positive yields. 
Table 7

Global average for risk perception by type of fund

\begin{tabular}{|c|c|c|c|c|}
\hline \multirow{2}{*}{ Type of risk } & \multirow{2}{*}{ Variable $^{2}$} & \multicolumn{2}{|c|}{ Type of fund } & \multirow{2}{*}{ Test } \\
\hline & & BOVA11 & IMA & \\
\hline \multirow{2}{*}{ Mistrust } & Question 2 & 5.35 & 3.38 & Line*** and Bar*** \\
\hline & Question 6 & 5.34 & 4.20 & Bar*** \\
\hline \multirow{2}{*}{ Loss } & Question 3 & 5.46 & 4.23 & Line ${ }^{* * *}$ and Bar***i \\
\hline & Question 4 & 4.20 & 2.94 & Line*** and Bar*** \\
\hline \multirow{2}{*}{ Volatility } & Question 1 & 5.83 & 4.86 & Line $^{* * * i}$ and Bar***i \\
\hline & Question 5 & 4.20 & 3.66 & Line*** and Bar*** \\
\hline Saving Accounts Yields & Question 7 & 5.17 & 5.34 & Line $\mathrm{C}^{* * *}$ and Bar** $^{* *}$ \\
\hline
\end{tabular}

Note: $i . p$-value for significant interaction.

${ }^{*} p$-value $<0.1$; ** $p$-value $<0.05 ; * * * p$-value $<0.01$.

The last column indicates for which format ANOVA showed a difference between the averages. The content of the questions is presented in the Appendix. The superscript " $i$ " indicates a significant $p$-value for the interaction.

Source: Elaborated by the authors.

This result indicates that survey respondents felt less perceived risk and higher yields for the fixed-income fund, with the variable-income fund perceived as riskier and offering lower returns, thus confirming our third hypothesis.

However, it is worth mentioning that, although the measurement of perceived risk depends mainly on the format effect (fund value in line chart vs. monthly yield in bar chart) arising from how past performance is presented to respondents, their answers to the supplementary questions show no impact due to this effect. The individual, therefore, is willing to pay a similar amount regardless of the presentation format (question 9), assigning the same value to past performance information (question 11).

\section{CONCLUSIONS}

The results of this study indicate, in general, that format effects affect the respondent's risk perception for the two types of fund (fixed-income and variable-income) in opposite ways: while for fixed-income IMA-General index the line chart increases risk perception, for BOVA11 variable-income index the bar chart gives the feeling of a riskier investment.

Established behavioral theories, such as loss aversion (Kahneman \& Tversky, 1979), may explain our findings regarding both the higher perceived risk for BOVA11 and the lower expected yields when past performance is presented in terms of monthly yields; or salient comparison standards (Mussweiler \& Schneller, 2003) can be used to explain the greater perceived risk for IMA-General when less past performance information is presented ("short" time horizon chart), especially when using the fund value format; or even use Griffin and Tversky's (1992) concepts of strength vs. weight to address the greater expected yields for IMA compared with BOVA11 in line chart presentations.

It is also important to highlight that the information disclosed in financial services agents' advertisements is currently presented in the form of line charts similar to those used in this study. Although the information is presented in terms of yields, the chart is essentially the same: presenting fund value on a daily basis is nothing more than presenting accumulated yields for the time horizon of interest. That is, these ads use a chart format that, according to our study's findings, leads to a decrease in risk perception and to higher perceived returns for the variable-income fund (thus inflating the perception of gains in the risk-return ratio); leads to higher perceived returns for the fixed-income fund; and, despite leading to a higher perceived risk in the bar chart presentation for the fixed-income fund, this format still makes the fixedincome fund to be perceived as less riskier in comparison with the variable-income fund.

Moreover, compared with the study by Diacon and Hasseldine (2007), our study's findings are convergent with regard to the risk perception for the variable-income fund, both for the format effect and for the timescale effect. They differ, however, in the expected returns on the variableincome fund, and in the risk perception and expected returns on the fixed-income fund. In addition, the study by Vrecko, Klos, and Langer (2009) corroborates the findings of this study, concluding that the investor's preference for 
investments with more asymmetric distributions, either right- or left-skewed, is strongly dependent on the asset presentation format, indicating that these preferences occur because different presentation formats highlight specific aspects of the asset.

Finally, due to the fact that, in this study, we identified the presence of framing effects, it becomes relevant to consider regulatory mechanisms to induce the establishment of format standards for investment performance presentation, allowing investors to make unbiased comparisons between investment options. To this end, we suggest that further research should be conducted to determine whether a more adequate graphic presentation of performance information can be achieved, thus assisting in developing new regulation. In addition, this study has a limitation due to the small sample used, suggesting that new studies should be carried out with a larger number of participants in order to confirm whether our findings about the impact of framing effects are recurrent.

\section{REFERENCES}

Associação Brasileira das Entidades dos Mercados Financeiro e de Capitais (Anbima). (2019a). Código Anbima de regulação e melhores práticas para distribuição de produtos de investimento. Recuperado de https://www.anbima.com. br/data/files/1B/E6/9B/3D/3F37061065B41706A8A80AC2/ Codigo-de-Distribuicao-de-Produtos-de-InvestimentoAudiencia-Publica.pdf.

Associação Brasileira das Entidades dos Mercados Financeiro e de Capitais (Anbima). (2019b). Consolidado mensal estatítica de varejo. Recuperado de http://www.anbima.com. br/pt_br/informar/estatisticas/varejo-private-e-gestores-depatrimonio/varejo-consolidado-mensal.htm.

Associação Brasileira das Entidades dos Mercados Financeiro e de Capitais (Anbima). (2016). Decisão de investimento envolve conflito entre prazer imediato e poupança. Recuperado de http://www.anbima.com.br/en_us/pt_br/noticias/decisaode-investimento-envolve-conflito-entre-prazer-imediato-epoupanca.htm.

Associação Brasileira das Entidades dos Mercados Financeiro e de Capitais (Anbima). (2018a). Mais da metade dos brasileiros não poupa para a aposentadoria e espera contar com os recursos da previdência social. Recuperado de http:// www.anbima.com.br/pt_br/imprensa/mais-da-metade-dosbrasileiros-nao-poupa-para-a-aposentadoria-e-espera-contarcom-os-recursos-da-previdencia-social.htm.

Associação Brasileira das Entidades dos Mercados Financeiro e de Capitais (Anbima). (2018b). Raio X do investidor: brasileiro não se prepara para a aposentadoria. Recuperado de http:// www.anbima.com.br/pt_br/noticias/raio-X-do-investidorbrasileiro-nao-se-prepara-para-a-aposentadoria.htm

Biernacki, P., \& Waldorf, D. (1981). Snowball Sampling: Problems and Techniques of Chain Referral Sampling. Sociological Methods \& Research, 10(2), pp. 141-163.

BlackRock. (2019). iShares Ibovespa Fundo de Índice. Recuperado de https://www.blackrock.com/br/products/251816/isharesibovespa-fundo-de-ndice-fund.

Bobak, M., \& Gjonca, A. (2001). The seasonality of live birth is strongly influenced by socio-demographic factors. Human Reproduction, 16(7), pp. 1512-1517.
Bolsa, Brasil, Balcão (B3). (2019). B3 lança pesquisa "Ecossistema do Investidor Brasileiro". Recuperado de http://www.b3.com. br/pt_br/noticias/relacionamento.htm.

Chagas, E. F. (2016). Módulo 5: análise multivariada no SPSS. Marília, SP: Unesp.

Comissão de Valores Mobiliários (CVM). (2014). Instrução $n^{o}$ 555. Recuperado de http://conteudo.cvm.gov.br/legislacao/ instrucoes/inst555.html.

Comissão de Valores Mobiliários (CVM). (2013). Intrução nº 539. Recuperado de http://www.cvm.gov.br/legislacao/instrucoes/ inst539.html.

Creswell, J. W. (2007). Métodos qualitativo, quantitativo e misto (2a ed.). (L. d. Rocha, Trad.) Porto Alegre, RS: Aritmed.

Diacon, S., \& Ennew, C. (2001). Consumer perceptions of financial risk. Geneva Papers on Risk and Insurance - Issues and Practice, 26(3), 389-409.

Diacon, S., \& Hasseldine, J. (2007). Framing effects and risk perception: The effect of prior performance presentation format on investment fund choice. Journal of Economic Psychology, 28(1), 31-52.

Dickert-Conlin, S., \& Chandra, A. (1999). Taxes and the timing of births. Journal of Political Economy, 107(1), 161-177.

Ganzach, Y. (2000). Judging risk and return of financial assets. Organization Behavior and Human Decision Processes, 83(2), 353-370.

Gentile, M., Linciano, N., Lucarelli, C., \& Soccorso, P. (2015). Financial disclosure, risk perception and investment choices. Evidence from a consumer testing exercise, Research Papers, 82.

Goeking, W. (2018). 85\% dos brasileiros ainda estão na poupança, mas juro menor leva investidores para fundos. InfoMoney. Recuperado de https://www.infomoney.com. br/onde-investir/poupanca/noticia/7281813/85-dosbrasileiros-ainda-estao-na-poupanca-mas-juro-menor-levainvestidores-para-fundos

Griffin, D., \& Tversky, A. (1992). The weighing of evidence and the determinants of confidence. Cognitive Psychology, 24(3), 411-435. 
Haandrikman, K. (2004). Seasonality of births in the Netherlands: Changing patterns due to conscious planning. In Annual Meeting of the Population Association of America (pp. 1-17). Boston, MA.

Jordan, J., \& Kaas, K. P. (2002). Advertising in the mutual fund business: The role of judgemental heuristics in private investors' evaluation of risk and return. Journal of Financial Services Marketing, 7(2), 129-140.

Kahneman, D. (1999). Objective happiness. Well-being: The Foundations of Hedonic Psychology, 3(25), 1-23.

Kahneman, D. (2012). Rápido e devagar: duas formas de pensar. (C. A. Leite, Trad.). Rio de Janeiro, RJ: Objetiva.

Kahneman, D., \& Tversky, A. (1979). Prospect theory: An analysis of decision under risk. Econometrica, 47(2), 263-291.

Kaufmann, C., Weber, M., \& Haisley, E. (2013). The role of experience sampling and graphical displays on one's investment risk appetite. Management Science, 59(2), 323-340.

Mitchell, O. S., \& Utkus, S. P. (2004). Pension design and structure: New lessons from behavioral finance. Oxford: Oxford University Press.

Mukerjee, R., \& Wu, C.-F. (2011). A modern theory of factorial designs. New York, NY: Springer.

Mullainathan, S., \& Thaler, R. H. (2000). Behavioral economics. NBER Working Paper Series (7948).

Mussweiler, T., \& Schneller, K. (2003). "What goes up must come down" - How charts influence decisions to buy and sell stocks. The Journal of Behavioral Finance, 4(3), 121-130.

Park, E., Cho, M., \& Ki, C.-S. (2009). Correct use of repeated measures analysis of variance. Korean Journal of Laboratory Medicine, 29(1), 1-9.

Pinheiro, R. P. (2008). Educação financeira e previdenciária, a nova fronteira dos fundos de pensão. In A. Reis (Org.), Fundos de pensão e mercado de capitais. São Paulo: Peixoto Neto.
Polasek, O., Koleie, I., Vorko-Jovié, A., Kern, J., \& Rudan, I. (2005). Seasonality of births in Croatia. Collegium Antropologicum, 29(1), 249-255.

Savoia, J. F., Saito, A. T., \& Santana, F. A. (2007). Paradigmas da educação financeira no Brasil. Revista de Administração Pública, 41(6), 1121-1141.

Silva, J. T., Barbosa, P. D., Teixeira, L. A., \& Reis Neto, M. T. (2010). Comportamentos relacionados à decisão de compra de papéis Bovespa: a inflência do message framing no pequeno investidor mineiro. Revista Eletrônica de Estratégia e Negócios, 3(2), 118-139.

Singh, J., \& Sirdeshmukh, D. (2000). Agency and trust mechanisms in consumer satisfaction and loyalty judgments. Journal of the Academy of Marketing Science, 28, 150-167.

Sun, Y., Li, S., \& Bonini, N. (2010). Attribute salience in graphical representations affects evaluation. Judgement and Decision Making, 5(3), 151-158.

Thaler, R. H., \& Benartzi, S. (2007). The behavioral economics of retirement savings behavior. Washington, DC: AARP.

Tversky, A., \& Kahneman, D. (1984). Choice, values and frames. The American Psychologist, 39(4), 341-350.

Tversky, A., \& Kahneman, D. (1981). The framing of decisions and the psychology of choice. Science, 211, 453-458.

Vinnuto, J. (2014). A amostragem em bola de neve na pesquisa qualitativa: um debate em aberto. Temáticas, 22(44), 203-220.

Vrecko, D., Klos, A., \& Langer, T. (2009). The impact of presentations format and self-reported risk aversion on revealed skewness preferences. Decision Analysis, 6(2), 57-74.

Weber, E. U., Siebenmorgen, N., \& Weber, M. (2005). Communicating asset risk: How name recognition and the format of historic volatility information affect risk perception and investment decisions. Risk Analysis, 25(3), 597-609. 


\section{APPENDIX}

The Portuguese version of the questionnaire used in this study present some differences in relation to the original English version used in the study by Diacon and Hasseldine (2007), which were maintained in the English version presented below.

\section{Research instrument}

Question 1

A friend (João) has asked you for some advice on how he should invest money towards his retirement. He intends to make regular contributions to a retirement savings plan of $\mathrm{R} \$ 600$ a month over the next 10 years. This amount will be invested in one of two investment funds below. He wants you to help decide which fund to choose.

Please look at the charts below. They show the most recent performance of the two funds. The chart shows how the value of an investment in the fund has developed over time. Of course, the past performance of these funds is not necessarily a reliable guide to their future performance.

Question 2

Another friend (Pedro) also asked you for advice on how he should invest money towards his retirement. He intends to make regular contributions to a retirement savings plan of $R \$ 600$ a month over the next 10 years. This amount will be invested in one of two investment funds below. He wants you to help decide which fund to choose. Please look at the charts below. They show the most recent performance of the two funds in terms of monthly yields. Of course, the past performance of these funds is not necessarily a reliable guide to their future performance.

Questions about each fund:

Please choose one of the numbers on the 1 to 7 scale.

1. How much uncertainty is there in terms of the expected return for this product? (None) 1234567 (Very High)

2. Is there a risk of receiving unsound and biased information from market professionals who recommend this product? (No risk) 1234567 (High Risk)

3. How serious could the consequences of owning this product be, should it prove unsatisfactory? (Not serious) 1234567 (Very serious)

4. How great is the risk of your friend losing all the money put invested in this product? (No risk) 1234567 (Substantial risk)

5. What is the chance of the value of this investment going down or up over the next few years? (No chance at all) 1234567 (High chance)

6. How trustworthy are the professionals who manage such type of investment? (Completely) 1234567 (Not at all)

7. How does the return on this investment compare with the expected return on a society savings account? (Much lower) 1234567 (Much higher)

Questions about the choice between the two funds:

8. Which fund do you recommend as the most suitable means of investing for your friend's retirement?

9. What is the maximum amount he should pay for advice from a qualified financial adviser? (write only the round amount, if you think advice is unnecessary put 0)

10. How easy is it to understand the above performance charts? (Very easy) 1234567 (Very difficult)

11.Is information on past performance helpful in making investment decisions? (Helpful) 1234567 (Useless) 